\title{
Expression and Localization of Extracellular Matrix-Degrading Proteinases and Their Inhibitors in the Bovine Mammary Gland During Development, Function, and Involution
}

\author{
A. Rabot, ${ }^{*}$ F. Sinowatz, † B. Berisha, ${ }^{*}$ H. H. D. Meyer, ${ }^{*}$ and D. Schams ${ }^{* 1}$ \\ ${ }^{\star}$ Physiology Weihenstephan, Technical University Munich, Weihenstephaner Berg 3, D-85350 Freising, Germany \\ †Institute of Veterinary Anatomy, University of Munich, D-80539 Munich, Germany
}

\begin{abstract}
In degrading the extracellular matrix, matrix metalloproteinases (MMP) and the plasminogen activator (PA) system may play a critical role in extensive remodeling that occurs in the bovine mammary gland during development, lactation, and involution. Therefore, the aim of our study was to investigate the mRNA expression of MMP-1, MMP-2, MMP-14, MMP-19, tissue inhibitor of metalloproteinases (TIMP)-1, TIMP-2, urokinase-type PA, tissue-type PA, urokinase-type PA receptor, and PA inhibitor-1 by quantitative PCR and to localize with immunohistochemistry MMP-1, MMP-2, MMP-14, and TIMP-2 proteins in the bovine mammary gland during pubertal mammogenesis, lactogenesis, galactopoiesis, and involution. Expression of mRNA for each of the studied factors was relatively lower during galactopoiesis and early involution but was markedly increased during mammogenesis and late involution, 2 stages in which tissue remodeling is especially pronounced. The localization of proteins for MMP-1, MMP14, and TIMP-2 showed a similar trend with strong staining intensity in cytoplasm of mammary duct and alveolar epithelial cells during pubertal mammogenesis and late involution. Interestingly, MMP-2 protein was localized only in the cytoplasm of endothelial cells during late involution. Our study demonstrated clearly that expression of extracellular matrix-degrading proteinases coincides with a concomitant expression of their inhibitors. High expression levels of MMP, TIMP, and PA family members seem to be a typical feature of the nonlactating mammary gland.
\end{abstract}

Key words: matrix metalloproteinases, plasminogen activator, mammary gland, bovine

\section{INTRODUCTION}

The mammary gland undergoes substantial morphological changes during development, lactogenesis, ga-

Received June 21, 2006.

Accepted September 13, 2006.

${ }^{1}$ Corresponding author: physio@wzw.tum.de lactopoiesis, and involution. At puberty, the extent of mammary gland development accelerates with ductal elongation and branching, followed by lobulo-alveolar development and maturation during pregnancy. This results in fully functional differentiation and production of milk by the secretory epithelium during lactation. Degenerative events then take place during involution of the gland following cessation of lactation after weaning or the end of milking. These different stages of normal mammary development require a finely controlled degradation and remodeling of the extracellular matrix. Several proteinases are implicated in the turnover of the extracellular matrix. The matrix metalloproteinases (MMP) are considered the key enzymes in this process and can be divided into 8 groups according to their structure. Metalloproteinases are zinc-dependent endopeptidases that are usually secreted as soluble latent proenzymes, 6 of which are membrane bound. They are then activated in the extracellular environment by a variety of factors, including members of the plasminogen activator (PA) system. This system belongs to the serine proteinase family, the second main family of matrix-degrading proteinases. These proteins are involved in direct degradation of extracellular matrix substrates (Sternlicht and Werb, 2001) and the activation of MMP precursors at the cell surface through the urokinasetype PA (uPA), uPA receptor ( $\mathbf{u P A R}$ )/plasminogen cascade (Murphy et al., 1999). Plasmin is produced from its inactive zymogen precursor, plasminogen, through 2 PA, uPA and tissue-type PA (tPA). Plasminogen activation is limited by the action of PA inhibitor (PAI).

In addition to their classical role, the matrix-degrading proteinases also function to release growth factors and cytokines. This expands the repertoire of MMP actions to include modulation of cell growth (Sternlicht and Werb, 2001; Green and Lund, 2005).

Regulation of most of the MMP family members is tightly controlled and is 3-fold: at the level of gene transcription, enzyme activation, and the balance between MMP and their natural inhibitors, the tissue inhibitors of metalloproteinases (TIMP). Activation of the proenzymes and the function of the mature MMP can be inhibited by the binding of TIMP. 
Because extracellular matrix proteinases have been associated with tumor growth and metastasis (Egeblad and Werb, 2002), a considerable body of research exists concerning the expression and role of the MMP and inhibitors in the mammary gland in murine models (Benaud et al., 1998; Rudolph-Owen and Matrisian, 1998; Green and Lund, 2005). However, very few data concerning the bovine mammary gland are available, although events occurring during development of the mammary gland are critical to the success of the first lactation, and those occurring during involution are likely to influence the following lactating period. In the mouse, mammogenesis and early involution are clearly associated with an up-regulation of the expression and activity of ECM-degrading proteinases and a down-regulation of their inhibitors. This study aimed to verify whether these observations were also true for the bovine. To test this hypothesis, we established the expression pattern of some MMP and inhibitors in the bovine mammary gland in an attempt to further elucidate their role and possible importance in mammary development and mammary function. Profiles of mRNA expression of MMP-1, MMP-2, MMP-14, and MMP-19; TIMP-1 and TIMP-2; and members of the PA system, uPA, tPA, UPAR, and PAI-1 were determined for the bovine mammary gland at well-defined stages of development (lactogenesis, galactopoiesis, and involution) by real-time PCR. In addition, we analyzed the localization patterns of MMP-1, MMP-2, MMP-14, and TIMP-2 to evaluate the correlation with gene expression data and to determine which cell types were involved. By selecting different proteinases and their inhibitors, we tried to cover a wide range of substrates that could be degraded during development and remodeling associated with involution.

\section{MATERIALS AND METHODS}

\section{Animals}

The mammary glands from nonpregnant German Fleckvieh and Holstein Friesian cows (38 in total) were removed within 20 min of slaughter during defined stages. The classification of the animals was established as follows: 1) M: pubertal mammogenesis (18-moold heifers, $n=4$ ); 2) $\mathbf{L}$ : lactogenesis (onset of secretion during d 4 to 8 postpartum, $\mathrm{n}=5$ ); galactopoiesis: 3 ) G1: peak lactation ( 2 to 8 wk postpartum, $\mathrm{n}=5$ ); 4) G2: mid lactation (4 to $5 \mathrm{mo}, \mathrm{n}=4$ ); 5) G3: late lactation ( 8 to $12 \mathrm{mo}, \mathrm{n}=4$ ); involution (after dry off): 6) I1: 24 to $48 \mathrm{~h}(\mathrm{n}=5) ; 7) \mathbf{I} 2: 96$ to $108 \mathrm{~h}(\mathrm{n}=3) ; 8) ; \mathbf{I 3 :} 14$ to $28 \mathrm{~d}(\mathrm{n}=8)$. Small pieces ( 1 to $2 \mathrm{~g}$ ) of mammary tissue were frozen in liquid nitrogen and stored at $-80^{\circ} \mathrm{C}$ for RNA extraction or were fixed for immunohistochemistry study.

\section{Total RNA Extraction and Reverse Transcription}

Total RNA was isolated from tissues using an adapted guanidinium thiocyanate/phenol method as described previously (Plath et al., 1997). To quantify the amount of total RNA extracted, the optical density (OD) was determined with a spectrophotometer (Eppendorf, Hamburg, Germany) at 3 different dilutions of the final RNA preparations at $260 \mathrm{~nm}$, corrected by the 320 $\mathrm{nm}$ background absorption. The integrity of RNA was verified electrophoretically by ethidium bromide staining and by an $\mathrm{OD}_{260}: \mathrm{OD}_{280} \mathrm{~nm}$ absorption ratio of $>1.7$.

Synthesis of the first strand cDNA was performed in a volume of $40 \mu \mathrm{L}$ containing $1 \mu \mathrm{g}$ of RNA and 2,000 U of M-MLV reverse transcriptase (Promega, Mannheim, Germany) according to the manufacturer's instructions. A reaction without the reverse transcriptase enzyme was performed to detect residual DNA contamination.

\section{Real-Time PCR}

Primers for housekeeping and target genes were designed by use of a software program (HUSAR program; DKFZ, Heidelberg, Germany) according to published bovine sequences (Table 1). Quantitative real-time PCR was performed with a Rotor-Gene 3000 system (Corbett Research, Sydney, Australia). Polymerase chain reactions were carried out using a LightCycler DNA Master SYBR Green I kit (Roche Diagnostics, Mannheim, Germany) with $1 \mu \mathrm{L}$ of each cDNA in a $10-\mu \mathrm{L}$ reaction mixture $\left(3 \mathrm{~m} M \mathrm{MgCl}_{2}, 0.4 \mu M\right.$ of each forward and reverse primer, $1 \times$ LightCycler DNA Master SYBR Green I). After initial incubation at $95^{\circ} \mathrm{C}$ for $10 \mathrm{~min}$ to activate the Taq DNA polymerase, templates of all specific transcripts were generated with a 3 -segment amplification and quantification program $\left(95^{\circ} \mathrm{C}\right.$ for 10 $\mathrm{s}, 60^{\circ} \mathrm{C}$ for $10 \mathrm{~s}, 72^{\circ} \mathrm{C}$ for $15 \mathrm{~s}$ with a single fluorescence acquisition point) repeated for 40 cycles.

Confirmation of PCR product identity and specificity was obtained through melting curve analysis (RotorGene 3000 software, version 5.0; Corbett Research) and subsequent gel electrophoresis separation, in which PCR products showed a single band at the expected length.

The cycle threshold (CT) for the target gene and the CT for an endogenous control, the housekeeping gene $\beta$-actin, were determined for each sample (Rotor-Gene 3000 software, version 5.0; Corbett Research). Values were then normalized to the endogenous control according to the $\Delta \mathrm{CT}$ equation, where $\Delta \mathrm{CT}=\mathrm{CT}_{\text {target }}-$ $\mathrm{CT}_{\beta \text {-actin }}$ (Leutenegger et al., 2000; Livak and Schmittgen, 2001). 
Table 1. Sequences of primers used in PCR amplification reactions

\begin{tabular}{|c|c|c|c|}
\hline Gene $^{1}$ & Sequence $\left(5^{\prime}\right.$ to $\left.3^{\prime}\right)$ & $\begin{array}{l}\text { Product } \\
\text { size, } \\
\text { bp }\end{array}$ & $\begin{array}{l}\text { EMBL }^{2} \\
\text { accession } \\
\text { number }\end{array}$ \\
\hline$\beta$-Actin & $\begin{array}{l}\text { For AACTCCATCATGAAGTGTGACG } \\
\text { Rev GATCCACATCTGCTGGAAGG }\end{array}$ & 234 & U39357 \\
\hline MMP-1 & $\begin{array}{l}\text { For CAAACCAGGTGCAGGTATCG } \\
\text { Rev AAGGTCCGTAGATGGCCTG }\end{array}$ & 232 & NM174112 \\
\hline MMP-2 & $\begin{array}{l}\text { For CCCAGACAGTGGATGATGC } \\
\text { Rev TTGTCCTTCTCCCAGGGTC }\end{array}$ & 248 & NM174745 \\
\hline MMP-14 & $\begin{array}{l}\text { For ACTTGGAAGGGGGACACC } \\
\text { Rev AGGGGGCATCTTAGTGGG }\end{array}$ & 236 & AF144758 \\
\hline MMP-19 & $\begin{array}{l}\text { For TTTCAAGGGGGACTATGTGTG } \\
\text { Rev CAATAGAGAGCTGCATCCAGG }\end{array}$ & 240 & X92521 \\
\hline TIMP-1 & $\begin{array}{l}\text { For CATCTACACCCCTGCCATG } \\
\text { Rev CAGGGGATGGATGAGCAG }\end{array}$ & 231 & AF144763 \\
\hline TIMP-2 & $\begin{array}{l}\text { For GGGTCTCGCTGGACATTG } \\
\text { Rev TTGATGTTCTTCTCCGTGACC }\end{array}$ & 256 & AF144764 \\
\hline tPA & $\begin{array}{l}\text { For GGGGAAGCACAACCACTG } \\
\text { Rev AGCTGATCAGGATCCCCC }\end{array}$ & 263 & X85800 \\
\hline uPA & $\begin{array}{l}\text { For TGCAGCCATCTACAGGAGG } \\
\text { Rev TGGTGAGCAAGGCTCTCC }\end{array}$ & 240 & X85801 \\
\hline uPAR & $\begin{array}{l}\text { For TGTTTCCAGAAACCGCTACC } \\
\text { Rev AAGTGGAAGGTGTGGTTGTTG }\end{array}$ & 234 & S70635 \\
\hline PAI-1 & $\begin{array}{l}\text { For CAGCGACTTACTTGGTGAAGG } \\
\text { Rev TCCAGGATGTCGTAGTAACGG }\end{array}$ & 231 & X52906 \\
\hline
\end{tabular}

${ }^{1} \mathrm{MMP}=$ matrix metalloproteinase; TIMP = tissue inhibitor of metalloproteinases; $\mathrm{tPA}=$ tissue-type plasminogen activator; $\mathrm{uPA}=$ urokinase-type plasminogen activator; $\mathrm{uPAR}=\mathrm{uPA}$ receptor; $\mathrm{PAI}=$ plasminogen activator-inhibitor.

${ }^{2} \mathrm{EMBL}=$ European Bioinformatics Institute (Cambridge, UK).

\section{Statistical Analyses}

The statistical significance of differences in the $\Delta \mathrm{CT}$ values of examined factors was assessed by ANOVA, followed by the Holm-Sidak test. Differences were considered significant if $P<0.05$. A high cycle number indicated a low level of gene expression and vice versa. We expressed our experimental data as 20 minus the mean of the normalized cycle threshold $(20-\Delta \mathrm{CT}) \pm$ standard error of the means (SEM). Consequently, the more template present at the beginning of the reaction, the larger the $20-\Delta \mathrm{CT}$ value.

\section{Immunohistochemistry}

For histology and immunohistochemistry, tissue samples (approximately $5 \mathrm{~mm}$ thick) were fixed in Bouin's solution for $48 \mathrm{~h}$, dehydrated in a graded series of ethanol, cleared in xylene, and embedded in paraffin. Serial sections $(5-\mu \mathrm{m})$ were cut on a Leitz microtome and mounted on gelatine/chrom alum-coated glass slides.

Following deparaffinization, the presence of the proteinases was demonstrated immunohistochemically by the streptavidin-biotin horseradish peroxidase complex (ABC) technique (Hsu et al., 1981). To expose antigenic sites for proteinases, dewaxed sections were heated 4 times to $95^{\circ} \mathrm{C}$ in a $600-\mathrm{W}$ microwave oven, maintained for $5 \mathrm{~min}$, and allowed to cool for $20 \mathrm{~min}$. Endogenous peroxidase activity was then eliminated by incubation with a $0.5 \%$ (vol/vol) hydrogen peroxide solution in absolute methanol for $10 \mathrm{~min}$ at $20^{\circ} \mathrm{C}$. Nonspecific protein binding was eliminated by incubation with Protein Block Serum-Free (Dako, Hamburg, Germany) for 10 min at room temperature. Sections were then incubated overnight at $4^{\circ} \mathrm{C}$ with first antibodies, dilution 1:100: polyclonal anti-MMP-1, monoclonal anti-MMP-2 (clone $\mathrm{Ab}-4)$; polyclonal anti-TIMP-2; polyclonal anti-MMP-14 (clone Ab-1; NeoMarkers, Fremont, CA). Incubation for 30 min with biotinylated porcine antirabbit IgG at a 1:100 or 1:300 dilution and with biotinylated rabbit antimouse IgG, 1:300 (Dako) followed. The sections were then reacted with $\mathrm{ABC}$ reagent from a commercial kit (Dako). The bound complex was made visible by reaction with $0.05 \% 3,3^{\prime}$-diaminobenzidine hydrochloride and $0.0006 \%$ hydrogen peroxide in $0.1 \mathrm{M}$ PBS. Between each step, sections were washed 3 times in PBS. All incubations were carried out in humidified chambers to prevent evaporation. Sections were counterstained in Mayer's hematoxylin, dehydrated, cleared, and mounted.

Controls were performed by 1 ) replacing the primary antibody with nonimmune serum; 2) substituting the 
primary antibody with buffer; 3) replacing the secondary antibody with buffer; and 4) incubating with diaminobenzidine reagent alone to exclude the possibility of nonsuppressed endogenous peroxidase activity. Lack of detectable staining of tissue elements in the controls demonstrated the specificity of the reactions. Positive controls were performed with bovine placental tissue to test the primary antibodies.

\section{RESULTS}

\section{Expression and Tissue Distribution of MMP Family Members}

The mRNA expression data for MMP and TIMP are shown in Figure 1, and the localization and staining patterns of the proteins are shown in Figure 2. The level of expression of MMP-1 transcripts did not change significantly across the stages examined (Figure 1A). By immunohistochemistry, during pubertal mammogenesis (heifers), the mammary duct epithelial cells were strongly immunoreactive (Figure 2, panel 2), stained weakly during lactation (Figure 2, panel 3), and strongly stained again during involution (Figure 2 , panel 4 ). The protein was distinctly detected in the cytoplasm of the epithelial cells. The negative control of heifer tissue (replacement of the primary antibody with nonimmune serum) showed no staining at all (Figure 2, panel 1).

Expression of MMP-2 mRNA was highest during pubertal mammogenesis and lactogenesis, significantly decreased during galactopoiesis, and further decreased during early involution (I2), followed by a significant increase (I3; Figure 1B). The only positive staining for MMP-2 detected in the mammary gland was during involution and was restricted to endothelial cells of blood vessels (Figure 2, panel 5).

Matrix metalloproteinase-14 and TIMP-2 presented the same profile of mRNA expression. Their mRNA levels decreased constantly from mammogenesis to galactopoiesis, were stable until the latest stage of involution, and tended to recover to a level comparable to that in mammogenesis (Figure 1C and 1D). Mammary duct epithelial cells of heifers were distinctly stained with antibody to MMP-14 (Figure 2, panel 6) but alveolar epithelial cells were poorly stained at all other stages examined (data not shown). The insert in Figure 2, panel 6, shows a positive control for MMP-14 (giant cells of bovine placenta). In contrast, mammary duct epithelial cells in heifers (Figure 2, panel 7) and alveolar cells (data not shown) of all other stages stained only weakly to TIMP-2. In Figure 2, panel 8, a negative control is presented in heifer tissue as well as a positive control in the insert (bovine placenta with stained giant cells). Table 2 summarizes the immunochemistry data indicating the relative intensity of staining and the cell types concerned.

Expression of MMP-19 transcripts was high during mammogenesis but was strongly down-regulated during lactation until the last stage of involution, when the transcripts recovered their initial level of expression (Figure 1E). Tissue inhibitor of metalloproteinase-1 mRNA was also expressed with a significantly higher value during pubertal mammogenesis, followed by down-regulation during lactation until early involution, with an increase again in late involution (Figure $1 \mathrm{~F}$ ).

\section{Expression of PA Family Members}

The mRNA expressions for PA, PAI-1, and UPAR are shown in Figure 3. The expression of uPA mRNA was consistently high during pubertal mammogenesis and lactogenesis but was significantly decreased during late lactation and early involution, followed by a significant increase in late involution (Figure $3 \mathrm{~A}$ ). In contrast, tPA expression remained constant across stages (Figure 3C). Expression of mRNA of the uPAR was up-regulated during mammogenesis and late involution and exhibited relatively low expression during other stages (Figure 3B). Similarly, PAI-1 mRNA was significantly higher during mammogenesis and lactogenesis but also tended to be higher during late involution (Figure 3D).

\section{DISCUSSION}

\section{Prelactational Development}

Mammogenesis occurs in 2 steps: the first one, early mammogenesis, consists of the construction of a branched ductal network throughout the mammary fat pad. The final developmental fate of the udder is fulfilled only when pregnancy occurs, under the impulse of reproductive hormones. As expected, our study demonstrates that matrix-degrading proteinases are expressed and up-regulated in the glands of virgin cows. Matrix metalloproteinase-2 expression and activity were also detected in developing mouse mammary tissue (Witty et al., 1995; Fata et al., 1999). Despite evidence in our study that mRNA expression of MMP-2 was up-regulated during mammogenesis and lactogenesis, the protein was not detected at this stage. The failure to detect MMP-2 protein is puzzling and unexplained. However, because MMP-14 is an activator of MMP-2 activity (Rudolph-Owen and Matrisian, 1998; Egeblad and Werb, 2002), it is logical to detect a synchronized expression of this factor.

Up-regulation of MMP-19 expression in nonlactating mammary tissue (i.e., that from virgin cows and postinvolution glands) corresponds with the study by Djonov et al. (2001) on human mammary tissue. High uPA and 

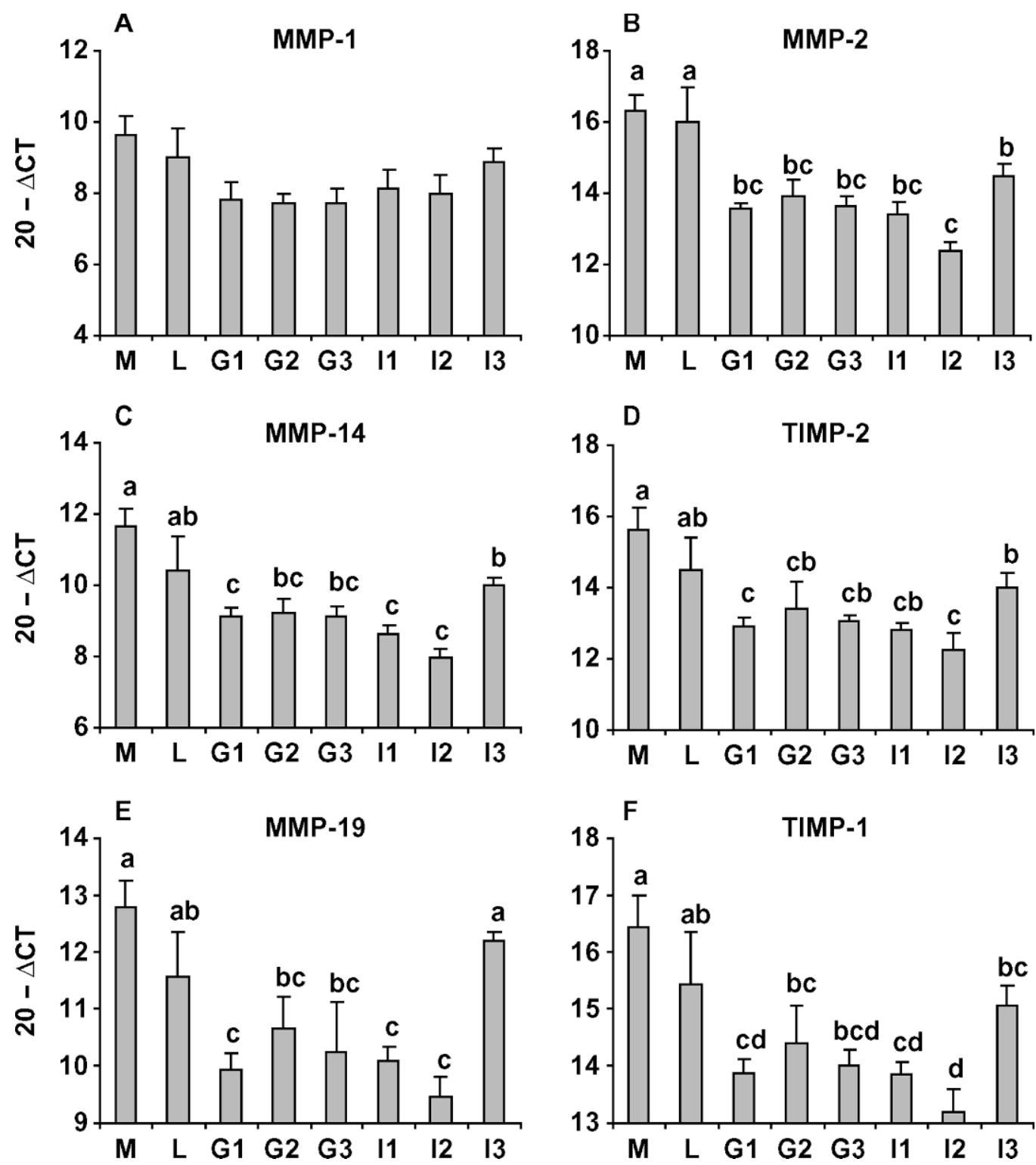

Figure 1. Messenger RNA expression of matrix metalloproteinase (MMP) family members in bovine mammary gland tissue. M: pubertal mammogenesis (18-mo-old heifers, $\mathrm{n}=4$ ); L: lactogenesis (onset of secretion during d 4 to 8 postpartum, $\mathrm{n}=5$ ); G1: galactopoiesis peak lactation (2 to 8 wk postpartum, $\mathrm{n}=5$ ); G2: galactopoiesis midlactation $(4$ to $5 \mathrm{mo}, \mathrm{n}=4)$; G3: galactopoiesis late lactation $(8$ to $12 \mathrm{mo}$, $\mathrm{n}=$ 4); I1: early involution (24 to $48 \mathrm{~h}$ after the end of milking, $\mathrm{n}=5$ ); I2: involution (96 to $108 \mathrm{~h}, \mathrm{n}=3$ ), I3: late involution (14 to $28 \mathrm{~d}$, $\mathrm{n}=8$ ). Results represent 20 minus means of $\Delta \mathrm{CT}$ (cycle threshold) \pm SEM from $\mathrm{n}=3$ to 8/group. Different letters indicate different means $(P<$ 0.05). TIMP $=$ Tissue inhibitor of metalloproteinases.

tPA levels in the developing bovine mammary gland are consistent with the fact that plasminogen plays an important role in branching morphogenesis (Busso et al., 1989; Delannoy-Courdent et al., 1996; Simian et al., 2001). Given that the PA system was also proposed to participate in activating MMP (Simian et al., 2001; Curry and Osteen 2003), it is not surprising to observe an elevation of the expression of its members when MMP are active.
Interestingly, TIMP are up-regulated during mammogenesis, although they have an inhibitory effect on morphogenesis (Fata et al., 1999). This most likely is to facilitate normal udder growth rather than uncontrolled proliferation. The up-regulation of TIMP-2 expression is expected because this factor, along with MMP-14, is required for the activation of MMP-2 (Wang et al., 2000). However, the TIMP-2 protein seems to be present at a constant level throughout the development 

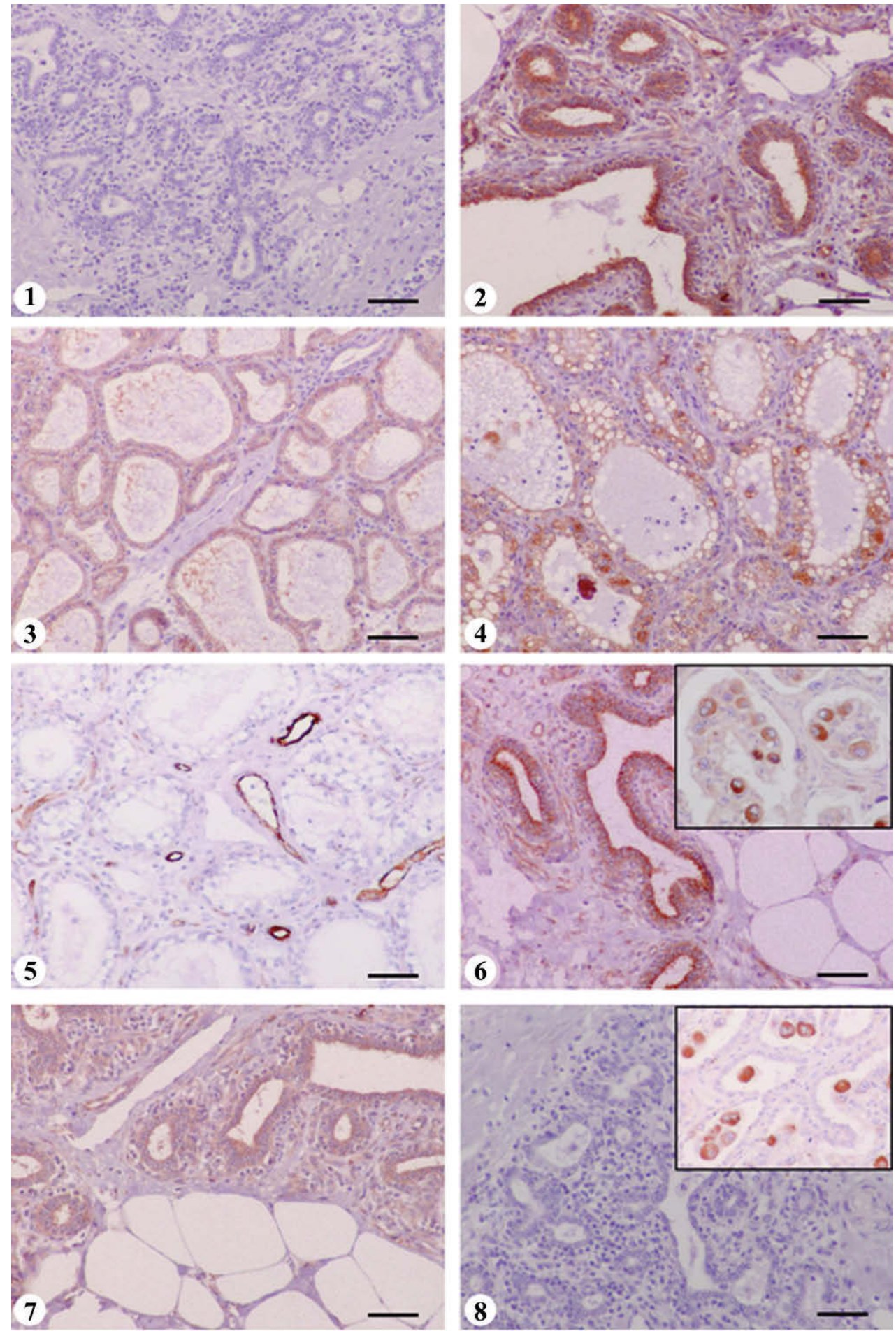

Figure 2. Immunohistochemical localization of matrix metalloproteinase (MMP)-1, MMP-2, and tissue inhibitor of metalloproteinase (TIMP)-2. Matrix metalloproteinase-1: Pubertal mammogenesis (heifers). No signal is visible on the negative control where MMP-1 primary antibody has been replaced with nonimmune serum (panel 1; bar: $100 \mu \mathrm{m}$ ). The ductular epithelial cells are strongly stained for MMP-1 at pubertal mammogenesis (panel 2; bar: $50 \mu \mathrm{m}$ ), appear moderately stained at galactopoiesis, 2 to 8 wk postpartum (panel 3; bar: $50 \mu \mathrm{m}$ ), and show a strong signal again in late involution, $28 \mathrm{~d}$ (panel 4; bar: $35 \mu \mathrm{m}$ ). Matrix metalloproteinase-2: Only vascular endothelial cells display distinct immunostaining at late involution (panel 5; bar: $50 \mu \mathrm{m}$ ). Matrix metalloproteinase-14: Duct epithelial cells are distinctly stained during pubertal mammogenesis. The insert shows giant cells of bovine placenta as the positive control (panel 6; bar: $100 \mu \mathrm{m}$ ). Tissue inhibitor of metalloproteinase-2: Epithelial cells from the mammary duct show a weak staining during pubertal mammogenesis (panel 7; bar: $100 \mu \mathrm{m})$. Negative and positive (insert, giant cells of bovine placenta) controls for TIMP-2 antibody (panel 8, bar: $100 \mu \mathrm{m}$ ). 
Table 2. Summary of the intensity of the immunostaining for each antibody, tissue area, and stage of development in bovine mammary gland tissue ${ }^{1}$

\begin{tabular}{lllll}
\hline Antibody $^{2}$ & Tissue area & Mammogenesis & Lactation & Involution \\
\hline MMP-1 & Ductal epithelial cells & +++ & + & +++ \\
MMP-2 & Endothelial cells & - & - & +++ \\
MMP-14 & Ductal epithelial cells & ++ & - & - \\
& Alveolar cells & + & + & + \\
TIMP-2 & Ductal epithelial cells & + & + & + \\
& Alveolar cells & + & + & + \\
\hline
\end{tabular}

${ }^{1}$ From - (no staining) to +++ (very strong intensity).

${ }^{2} \mathrm{MMP}=$ Matrix metalloproteinase; TIMP $=$ tissue inhibitor of metalloproteinase.

period. This suggests that the formation of branching ducts requires a tightly regulated ratio of MMP and inhibitors.

The case of MMP-1 is quite interesting. Sorrell et al. (2005) demonstrated in the mouse that expression levels of most MMP genes are actually low and, moreover, that they stay constant throughout development. Therefore, the absence of significant variation of MMP1 expression in the cow would not be unexpected if the protein were not remarkably up-regulated at late involution. We cannot reach a conclusion regarding regulation at the zymogen level because the anti-MMP-1 recognized both the zymogen and the active form of the protein. Because mRNA expression and the presence of the protein were not correlated for MMP-2 and MMP1 , we assume that regulation at the transcript level is probably not the most important in the mechanisms controlling the activity of the MMP.
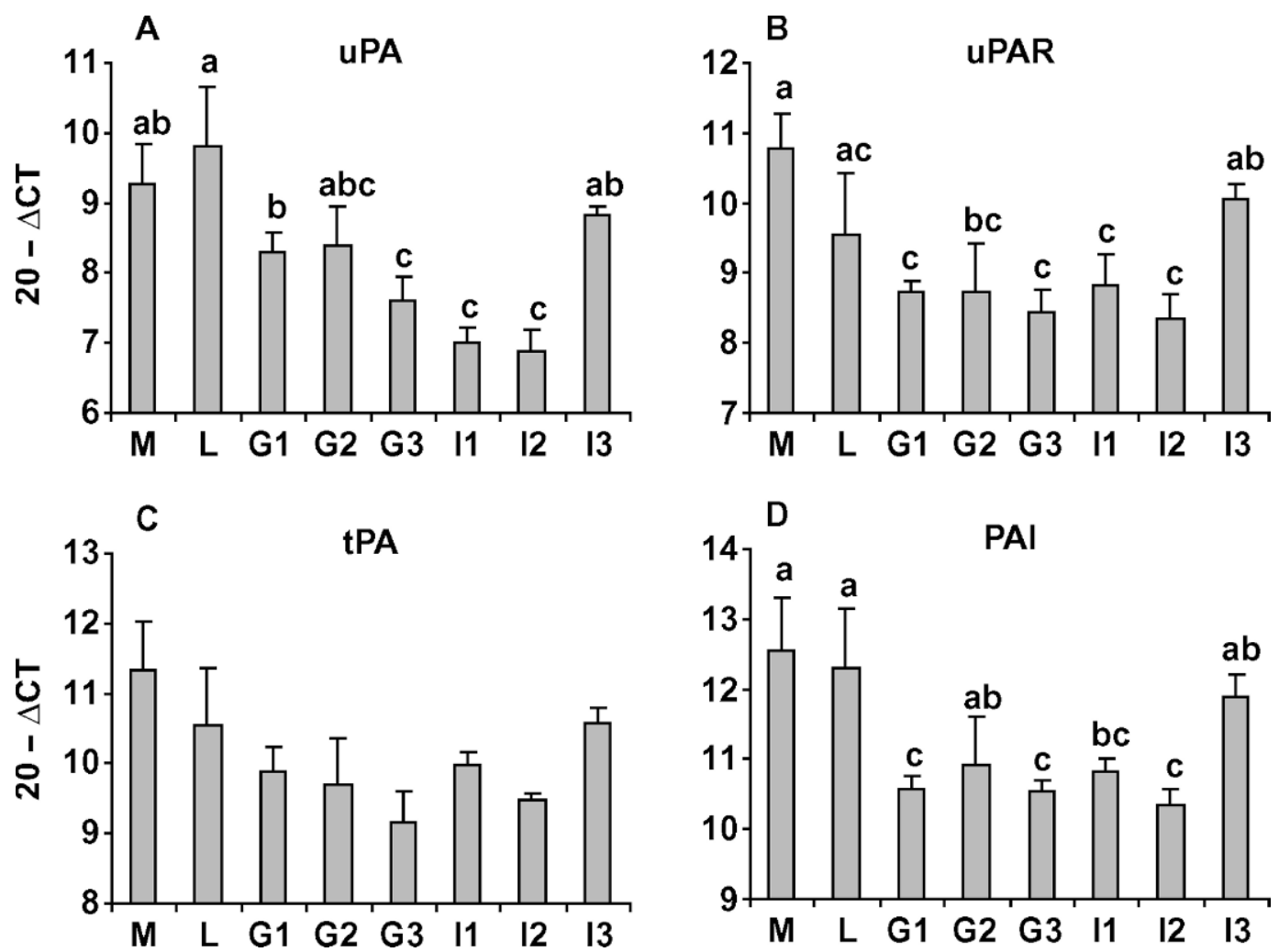

Figure 3. Messenger RNA expression of plasminogen activator (PA) system members in bovine mammary gland tissue. M: pubertal mammogenesis (18-mo-old heifers, $\mathrm{n}=4$ ); L: lactogenesis (onset of secretion during d 4 to 8 postpartum, $\mathrm{n}=5$ ); G1: galactopoiesis peak lactation ( 2 to 8 wk postpartum, $\mathrm{n}=5$ ); G2: galactopoiesis midlactation ( 4 to $5 \mathrm{mo}, \mathrm{n}=4$ ); G3: galactopoiesis late lactation $(8$ to 12 mo, $\mathrm{n}=$ 4); I1: early involution ( 24 to $48 \mathrm{~h}$ after the end of milking, $\mathrm{n}=5$ ); I2: involution (96 to $108 \mathrm{~h}, \mathrm{n}=3$ ), I3: late involution (14 to $28 \mathrm{~d}$, $\mathrm{n}=8$ ). Results represent 20 minus the means of $\Delta \mathrm{CT}$ (cycle threshold) \pm SEM from $\mathrm{n}=3$ to 8/group. Different letters indicate different means $(P$ $<0.05)$. $\mathrm{uPA}=$ Urokinase-type PA; uPAR = urokinase-type PA receptor; $\mathrm{tPA}=$ tissue-type PA; PAI = PA inhibitor. 


\section{Lactation}

Most of the matrix-degrading proteinase transcripts studied were down-regulated during different stages of lactation in the bovine mammary gland. Our data are in agreement with studies showing low levels or no detection at all of MMP in the lactating murine mammary gland (Strange et al., 1992; Li et al., 1994; Lund et al., 1996). This is consistent with the presence of a well-defined, intact basement membrane supporting the differentiated, milk-secreting epithelial cells. The need for an intact basement membrane in the maintenance of a functional, differentiated phenotype in mammary epithelial cells is known (Sympson et al., 1994). During all stages of lactation, expression of MMP inhibitors, as well as members of the PA-plasmin system, is also repressed except for uPA and tPA, which are expressed at a stable level. This last observation is in contradiction with the study of Busso et al. (1989), in which both uPA and tPA expression decreased in lactating murine glands, but the data are in accordance with the increased concentrations of plasmin and plasminogen during lactation in cows detected by Politis et al. (1989).

\section{Involution}

After cessation of lactation by removing suckling young or by suspending milking (dry period), the mammary gland undergoes involution. In rodents, involution has been characterized as a 2-stage process. The first stage is characterized by induction of apoptosis of mammary epithelial cells without visible degradation of the extracellular matrix, and the second phase is characterized by activation of proteinases that destroy the lobular-alveolar structure of the gland and trigger remodeling of the extracellular matrix (Lund et al., 1996). Epithelial cells lose their adhesion to a basement membrane, which is destroyed by the increased proteinase activity and, as a result, the cells lose survival signals generated by the extracellular matrix (Wiseman and Werb, 2002). These events result in a return to the fully regressed, nonfunctional stage of the mammary gland in preparation for a new reproductive cycle. Several matrix-degrading proteinases have been implicated in the degradation and remodeling of mouse mammary stroma during involution, including MMP-2 (Dickson and Warburton, 1992; Talhouk et al., 1992) and uPA (Busso et al., 1989). Indeed, PA play an important role during involution because postlactational involution has been demonstrated to be profoundly compromised in the absence of plasmin (Lund et al., 2000). Mammary involution proceeds more slowly in dairy animals than in rodents, and morphological changes that occur during the dry period are less pronounced. There is no significant tissue regression during the dry period prior to parturition in dairy cows, and even without the protective effect of a concurrent pregnancy, the alveolar structure is partially maintained for several weeks after cessation of milking (Capuco and Akers, 1999). Our data suggest that involution in the bovine occurs in 2 phases, consistent with those noted in mice: an initial one corresponding to the stages of I1 and I2 (1 to $5 \mathrm{~d}$ of involution), when expression of MMP and their inhibitors are strongly down-regulated, and another one corresponding to the later stage, I3 (14 to $28 \mathrm{~d}$ of involution), with an up-regulation of proteinases and members of the PA system. This is also reflected in immunohistochemistry data in which MMP-1 and MMP-2 proteins are more abundant during involution, in the epithelium for the first one and, interestingly, in the endothelial cells for the second one. This suggests different activities for these 2 proteinases. Matrix metalloproteinase- 2 has also been detected in stroma, epithelial, and myoepithelial cells in the murine model (Dickson and Warburton, 1992; Wiseman et al., 2003).

Despite a difference in timing between rodents and ruminants, involution involves similar physiological events in both species. Our data suggest that high expression of MMP and inhibitors is a characteristic feature of the "resting" mammary gland. Because this expression also corresponds with an elevation of morphogenic growth factor expression as transforming growth factor $\alpha$, fibroblast growth factor, and IGF (Plath et al., 1997, 1998; Plath-Gabler et al., 2001), one can assume that matrix-degrading proteinases are working synergistically with such factors. Studies to determine the nature of this relation and the influence that lactogenic hormones might have on their expression are warranted.

In general, the fluctuation in expression of the different transcripts measured were much less dramatic than in rodents. This can be explained by the fact that development and lactation periods of the bovine mammary gland are much longer than in the murine mammary gland (weeks for the mouse to a month for the cow). Consequently, in the cow, the action of matrix-degrading proteinases does not need to be as acute and intense as it is in the mouse.

\section{CONCLUSIONS}

This characterization study shows that all of the tested matrix-degrading proteinases and their inhibitors are up-regulated in stages in which the mammary gland undergoes extensive morphological modeling. Their localization is not confined to the alveolar epithelial cells but can also be observed in mammary duct epithelial cells and vascular endothelial cells. This indi- 
cates that matrix-degrading proteases might play a cellspecific role that highlights another level of control of their action. Matrix-degrading proteinases are under complex regulation to prevent inappropriate degradation as well as inappropriate proliferation of mammary tissue. Both growth factors and reproductive hormones influence this regulation, but by largely unknown mechanisms.

\section{ACKNOWLEDGMENTS}

We would like to thank M. Partsch for technical assistance and $\mathrm{H}$. Welter for his excellent help with realtime PCR method. The study was funded by the German Research Foundation (Scha257/13-3), and Aline Rabot was supported by the chèque insertion à l'international programme of the Conseil Régional de Bretagne.

\section{REFERENCES}

Benaud, C., R. B. Dickson, and E. W. Thompson. 1998. Roles of the matrix metalloproteinases in mammary gland development and cancer. Breast Cancer Res. Treat. 50:97-116.

Busso, N., J. Huarte, J. D. Vassalli, A. P. Sappino, and D. Belin. 1989. Plasminogen activators in the mouse mammary gland. Decreased expression during lactation. J. Biol. Chem. 264:7455-7457.

Capuco, A. V., and R. M. Akers. 1999. Mammary involution in dairy animals. J. Mammary Gland Biol. Neoplasia 4:137-144.

Curry, T. E., Jr., and K. G. Osteen. 2003. The matrix metalloproteinase system: Changes, regulation, and impact throughout the ovarian and uterine reproductive cycle. Endocr. Rev. 24:428-465.

Delannoy-Courdent, A., W. Fauquette, X. F. Dong-Le Bourhis, B. Boilly, B. Vandenbunder, and X. Desbiens. 1996. Expression of c-ets-1 and uPA genes is associated with mammary epithelial cell tubulogenesis or neoplastic scattering. Int. J. Dev. Biol. 40:1097-1108.

Dickson, S. R., and M. J. Warburton. 1992. Enhanced synthesis of gelatinase and stromelysin by myoepithelial cells during involution of the rat mammary gland. J. Histochem. Cytochem. 40:697-703.

Djonov, V., K. Hogger, R. Sedlacek, J. Laissue, and A. Draeger. 2001. MMP-19: Cellular localization of a novel metalloproteinase within normal breast tissue and mammary gland tumours. J. Pathol. 195:147-155.

Egeblad, M., and Z. Werb. 2002. New functions for the matrix metalloproteinases in cancer progression. Nat. Rev. Cancer 2:161-174.

Fata, J. E., K. J. Leco, R. A. Moorehead, D. C. Martin, and R. Khokha. 1999. Timp-1 is important for epithelial proliferation and branching morphogenesis during mouse mammary development. Dev. Biol. 211:238-254.

Green, K. A., and L. R. Lund. 2005. ECM degrading proteases and tissue remodelling in the mammary gland. Bioessays 27:894-903.

Hsu, S. M., L. Raine, and H. Fanger. 1981. Use of avidin-biotinperoxidase complex $(\mathrm{ABC})$ in immunoperoxidase techniques: $A$ comparison between $\mathrm{ABC}$ and unlabeled antibody (PAP) procedures. J. Histochem. Cytochem. 29:577-580.

Leutenegger, C. M., A. M. Alluwaimi, W. L. Smith, L. Perani, and J. S. Cullor. 2000. Quantitation of bovine cytokine mRNA in milk cells of healthy cattle by real-time TaqMan polymerase chain reaction. Vet. Immunol. Immunopathol. 77:275-287.

Li, F., R. Strange, R. R. Friis, V. Djonov, H. J. Altermatt, S. Saurer, H. Niemann, and A. C. Andres. 1994. Expression of stromelysin1 and TIMP-1 in the involuting mammary gland and in early invasive tumors of the mouse. Int. J. Cancer 59:560-568.
Livak, K. J., and T. D. Schmittgen. 2001. Analysis of relative gene expression data using real-time quantitative PCR and the 2- $\Delta \Delta$ C(T) method. Methods 25:402-408.

Lund, L. R., S. F. Bjorn, M. D. Sternlicht, B. S. Nielsen, H. Solberg, P. A. Usher, R. Osterby, I. J. Christensen, R. W. Stephens, T. H. Bugge, K. Dano, and Z. Werb. 2000. Lactational competence and involution of the mouse mammary gland require plasminogen. Development 127:4481-4492.

Lund, L. R., J. Romer, N. Thomasset, H. Solberg, C. Pyke, M. J. Bissell, K. Dano, and Z. Werb. 1996. Two distinct phases of apoptosis in mammary gland involution: Proteinase-independent and -dependent pathways. Development 122:181-193.

Murphy, G., H. Stanton, S. Cowell, G. Butler, V. Knauper, S. Atkinson, and J. Gavrilovic. 1999. Mechanisms for pro matrix metalloproteinase activation. APMIS 107:38-44.

Plath, A., R. Einspanier, C. Gabler, F. Peters, F. Sinowatz, D. Gospodarowicz, and D. Schams. 1998. Expression and localization of members of the fibroblast growth factor family in the bovine mammary gland. J. Dairy Sci. 81:2604-2613.

Plath, A., R. Einspanier, F. Peters, F. Sinowatz, and D. Schams. 1997. Expression of transforming growth factors $\alpha$ and $\beta-1$ messenger RNA in the bovine mammary gland during different stages of development and lactation. J. Endocrinol. 155:501-511.

Plath-Gabler, A., C. Gabler, F. Sinowatz, B. Berisha, and D. Schams. 2001. The expression of the IGF family and GH receptor in the bovine mammary gland. J. Endocrinol. 168:39-48.

Politis, I., E. Lachance, E. Block, and J. D. Turner. 1989. Plasmin and plasminogen in bovine milk: A relationship with involution? J. Dairy Sci. 72:900-906.

Rudolph-Owen, L. A., and L. M. Matrisian. 1998. Matrix metalloproteinases in remodeling of the normal and neoplastic mammary gland. J. Mammary Gland Biol. Neoplasia 3:177-189.

Simian, M., Y. Hirai, M. Navre, Z. Werb, A. Lochter, and M. J. Bissell. 2001. The interplay of matrix metalloproteinases, morphogens and growth factors is necessary for branching of mammary epithelial cells. Development 128:3117-3131.

Sorrell, D. A., M. Szymanowska, M. Boutinaud, C. Robinson, R. W. Clarkson, T. Stein, D. J. Flint, and A. F. Kolb. 2005. Regulation of genes encoding proteolytic enzymes during mammary gland development. J. Dairy Res. 72:433-441.

Sternlicht, M. D., and Z. Werb. 2001. How matrix metalloproteinases regulate cell behavior. Annu. Rev. Cell Dev. Biol. 17:463-516.

Strange, R., F. Li, S. Saurer, A. Burkhardt, and R. R. Friis. 1992. Apoptotic cell death and tissue remodelling during mouse mammary gland involution. Development 115:49-58.

Sympson, C. J., R. S. Talhouk, C. M. Alexander, J. R. Chin, S. M. Clift, M. J. Bissell, and Z. Werb. 1994. Targeted expression of stromelysin-1 in mammary gland provides evidence for a role of proteinases in branching morphogenesis and the requirement for an intact basement membrane for tissue-specific gene expression. J. Cell Biol. 125:681-693.

Talhouk, R. S., M. J. Bissell, and Z. Werb. 1992. Coordinated expression of extracellular matrix-degrading proteinases and their inhibitors regulates mammary epithelial function during involution. J. Cell Biol. 118:1271-1282.

Wang, Z., R. Juttermann, and P. D. Soloway. 2000. TIMP-2 is required for efficient activation of proMMP-2 in vivo. J. Biol. Chem. 275:26411-26415.

Wiseman, B. S., M. D. Sternlicht, L. R. Lund, C. M. Alexander, J. Mott, M. J. Bissell, P. Soloway, S. Itohara, and Z. Werb. 2003. Site-specific inductive and inhibitory activities of MMP-2 and MMP-3 orchestrate mammary gland branching morphogenesis. J. Cell Biol. 162:1123-1133.

Wiseman, B. S., and Z. Werb. 2002. Stromal effects on mammary gland development and breast cancer. Science 296:1046-1049.

Witty, J. P., J. H. Wright, and L. M. Matrisian. 1995. Matrix metalloproteinases are expressed during ductal and alveolar mammary morphogenesis, and misregulation of stromelysin-1 in transgenic mice induces unscheduled alveolar development. Mol. Biol. Cell 6:1287-1303. 